\title{
Characterization of women and youth smallholder agricultural entrepreneur's in rural irrigation schemes in Vhembe district, South Africa
}

Mavhungu, T.J. ${ }^{1}$, Nesamvuni, A.E. ${ }^{2}$, Tshikolomo, K.A. ${ }^{3}$, Raphulu, T. ${ }^{4}$, Van Niekerk, J.A..$^{5}$, Mpandeli, N.S. ${ }^{6}$, and Nesamvuni, A.E. ${ }^{7}$

Correspondence Author: A.E. Nesamvuni: nesamvunie@gmail.com

\begin{abstract}
The purpose of the study was to characterize irrigated smallholder agricultural enterprises (ISAEs) in selected areas of Vhembe District, Limpopo Province. The characterization focused on the geophysical environment and on participants in ISAEs. Precipitation was at most 460mmpa for villages along Madimbo Corridor and 701$1380 \mathrm{mmpa}$ for those along Mutale Valley, and temperatures were $38.1^{\circ} \mathrm{C}-44.0^{\circ} \mathrm{C}$ (Madimbo) and $30.0^{\circ} \mathrm{C}-40.0^{\circ} \mathrm{C}$ (Mutale). Groundwater supplemented surface water and was utilized more at Madimbo Corridor compared to Mutale Valley. The study area was characterized as semi-arid to sub-humid, hence technologies for efficient irrigation should be promoted. Participants in ISAEs were female (94.9\%), and adult (52.72\%) with low education levels $(67.7 \% \leq$ secondary education). The majority $(88.65 \%)$ were not formally employed $(54.61 \%$ selfemployed, 34.04\% full-time farmers). Participants experienced some level of poverty, 68.03 per cent received low household incomes (R1001-R5000/month), 77 per cent received social grants. Interestingly, the majority $(65.31 \%)$ stayed in multiple-roomed houses, had cement brick walls, and corrugated iron roofs (54.42\%), and all had electricity, a stove, and a fridge. Also, majority-owned radio (96.67\%), DSTV (87.45\%), vehicles (65.56\%), and cellphones. Participants mostly provided adequate food supply (91.84\%) with three meals/day (79.38\%) except during hard times where 49.56 per cent provided fewer meals mostly due to delayed readiness of farm produce. Strategies to empower ISAE participants to be more effective should consider their gender, age, education, and economic status estimated by income, asset ownership, and food security.
\end{abstract}

\footnotetext{
${ }^{1}$ Doctoral Student, Centre for Sustainable Agriculture, Rural Development and Extension, University of the Free State, Bloemfontein, 9300, South Africa jutasmavhungu@gmail.com, ORCID 0000-0002-4212-3290

${ }^{2}$ Professor, Centre for Sustainable Agriculture, Rural Development and Extension, University of the Free State, Bloemfontein, 9300, South Africa, nesamvuniAE@ufs.ac.za ORCID 0000-0002-3764-1683

3 Tshikolomo, K.A., Director Crop Production, Limpopo Department of Agriculture and Rural Development, Private Bag X9487, Polokwane, 0700, South Africa, tshikolomo@gmail.com, ORCID 0000-0003-0181-9416

${ }^{4}$ Scientist Manager, Limpopo Department of Agriculture and Rural Development, Private Bag X9487, Polokwane, 0700, South Africa, Thomas.raphulu@gmail.com, ORCID 0000-0002-0779-1779

${ }^{5}$ Professor, Centre for Sustainable Agriculture, Rural Development and Extension, University of the Free State, Bloemfontein, 9300, South Africa, vniekerkJA@ufs.ac.za, ORCID 0000-0001-9842-0641

${ }^{6}$ Executive, Manager, Water Research Commission, Lynwood Manor, Pretoria, 0081, South Africa, sylvesterm@wrc.org.za, ORCID 0000-0003-4925-6173

${ }^{7}$ Executive Dean, Faculty of Management Sciences, Faculty of Management Sciences, TUT, Staatsartillerie Rd, Pretoria West, 0183, South Africa, nesamvuniae@tut.ac.za ORCID 0000-0002-9434-8731
} 
S. Afr. J. Agric. Ext.

Vol. 49 No. 3, 2021: 104-122.

http://dx.doi.org/10.17159/2413-3221/2021/v49n3a12848
Mavhungu, Nesamvuni, Tshikolomo, Raphulu, van Niekerk, Mpandeli \& Nesamvuni

(License: CC BY 4.0)

Keywords: Vhembe District, Geo-physical environment, Irrigated smallholder agricultural enterprise, Madimbo Corridor, Mutale Valley

\section{INTRODUCTION}

Improving household livelihood through smallholder-irrigated agriculture will remain a key strategy for rural poverty alleviation in most of the low-income countries, where most of the rural poor depend directly or indirectly on agriculture. In support of the above, Water Research Commission (WRC, 2009) indicated that for many decades' smallholder irrigated agriculture has been considered to have the potential to generate economic development in poor and under-developed rural areas. The antiquity of smallholder-irrigated agriculture in South Africa specifies that it suffered considerable neglect and was a mixture of success and failure. Those may have been caused by the adverse effect of water unavailability, which resulted in decreasing agricultural production leading to food insecurity, unemployment, and poverty.

With improvements in infrastructure done over the years, it was anticipated that access to reliable water for irrigated smallholder agricultural enterprises (ISAEs) would lead to increased productivity and greater returns from farming. Coupled with the improved ability of ISAEs owners to innovate socially and technologically it was postulated that new opportunities would be opened for both on-farm and off-farm income. Hussain et al. (2004) corroborated the prospects for improvement of livelihoods and the quality of life in rural areas. However, the lack of information on ISAEs is still dire. The objectives of this study were to:

(1) Characterize the geophysical environment in which the ISAEs operated in the area under study with a focus on the existence of rivers, rainfall distribution, temperature, and the aridity index of the area under study; and

(2) Characterize the participants in ISAEs based on attributes such as demography, household livelihoods, and household food security.

The characterization of ISAEs would inform the development of (a) relevant technologies for improving production under the existing geophysical environment and (b) pertinent empowerment strategies for participants in the ISAEs.

\section{METHODOLOGY}

\subsection{Study Area}

The study was carried out in the Vhembe District Municipality of Limpopo Province. The specific areas were Madimbo Corridor under Musina Local Municipality and Mutale Valley under Thulamela Municipality. The focus was on irrigated enterprises that were reliant on private water supply (Madimbo Corridor) and those, which depended on communal water supply infrastructure that irrigated a huge cluster of plots (Mutale Valley). The main villages covered under Madimbo Corridor were Ha-Gumbu, Malale, Masea, Ngwele, Tshipise, and Nwanedi while those under Mutale Valley were Tshiombo, Matangari, and Maraxwe. The study area covered more than 2 270 ha of land. 
S. Afr. J. Agric. Ext.

Vol. 49 No. 3, 2021: 104-122.

http://dx.doi.org/10.17159/2413-3221/2021/v49n3a12848
Mavhungu, Nesamvuni, Tshikolomo, Raphulu, van Niekerk, Mpandeli \& Nesamvuni

(License: CC BY 4.0)

\subsection{Sampling Procedure}

Stratified random sampling was used to obtain a representative sample of villages and households for interview (Leedy et.al, 2005) with the target population being women and youth SHAEs. A two-stage random sampling process was conducted using the SURVEYSELECT procedure of SAS. The PROC SUREVEYSELECT allowed for probability-based random sampling where sampling in a category or class depended on the number of units within that class. The sampling was regarded as appropriate for handling selection bias.

\subsection{Data Collection}

A semi-structured household questionnaire was used to survey with an emphasis on women and youth ISAEs. The total number of ISAE owners interviewed was two hundred and ninety-four $(\mathrm{N}=294)$ with a response rate of 75 per cent. The sample was comprised of 71 youths aged 18 to 35 years old (56 females and 15 males) and 223 women of whom 153 were adults (36-59 years) and 70 pensioners ( $\geq 60$ years old).

\subsection{Data analysis}

The Statistical Package for the Social Sciences (SPSS) version 22 was used to analyze quantitative data. Descriptive statistics included frequency tables and measures of central tendency. Qualitative data were analyzed using MS Excel, themes for each question were created according to participant's responses and each response was coded accordingly. In some cases, these themes were further broken down into one or more relevant subthemes.

\section{RESULTS AND DISCUSSIONS}

According to Randela et. al. (2006) characterization of the geophysical environment of location of the ISAEs and of participants in these enterprises have some influence on the design and implementation of policies regulating the establishment of these enterprises. As alluded to earlier, the characterization could guide the development of relevant technologies to improve agricultural production under the existing geophysical environment and the design of pertinent strategies for the empowerment of participants in the ISAEs.

\subsection{Characterization of the geophysical environment of location of smallholder agricultural enterprise}

\subsubsection{Water sources}

The ISAEs investigated were all irrigated, hence their proximity to water sources remained important. The main rivers flowing through the study area were Sand, Mutamba, Nwanedi, and Mutale with boreholes more densely distributed in the southernmost Mutale Valley compared to the north most Madimbo Corridor (Figure 1). Surface water was the main source of supply with groundwater used as a supplementary source in the study area. The ISAEs located in the Madimbo Corridor (under villages of Ha-Gumbu, Malale, Masea, Ngwele, Tshipise, and Nwanedi) used more groundwater than their counterparts located in Mutale Valley (Tshiombo, Matangari, and Maraxwe). 


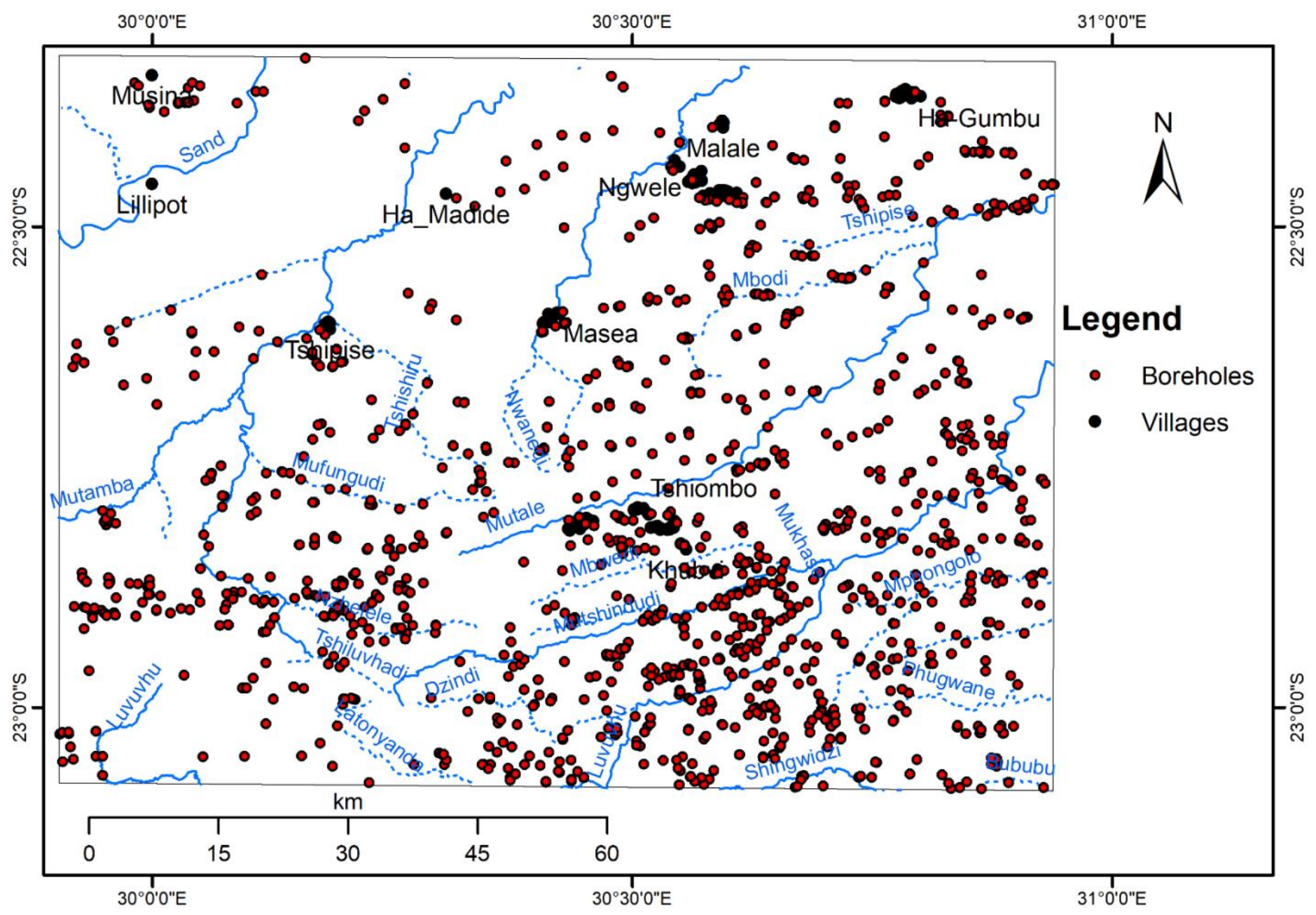

FIGURE 1: Spatial distribution of rivers and boreholes around selected villages of the location of irrigated smallholder agricultural enterprises in Vhembe District, Limpopo Province

With the boreholes more sparsely distributed in Madimbo Corridor, it may be inferred that their total yield was higher than that of the densely distributed boreholes in the Mutale Valley. The observation affirms earlier findings on the importance of groundwater in the Madimbo Corridor and broader Musina Municipal Area (Tshikolomo et al., 2013; Mpandeli \& Maponya, 2014). Adams (2013) in his extensive study on the potential of groundwater to support agriculture and other related sectors also recommended a broader review of the use of groundwater in the country. Although the relative use of surface and groundwater by ISAEs reportedly varied between Madimbo Corridor and Mutale Valley, the study area used both sources and would hence benefit from technologies promoting the efficient use of water from both sources.

\subsubsection{Climatic factors}

Rainfall and temperature are perhaps the two most important climatic factors for describing the geophysical environment for agricultural production. 


\section{(a) Rainfall}

According to Kotir (2011), precipitation is one of the key determinant factors for agricultural production in SubSaharan Africa because it is the sole source of water supply.

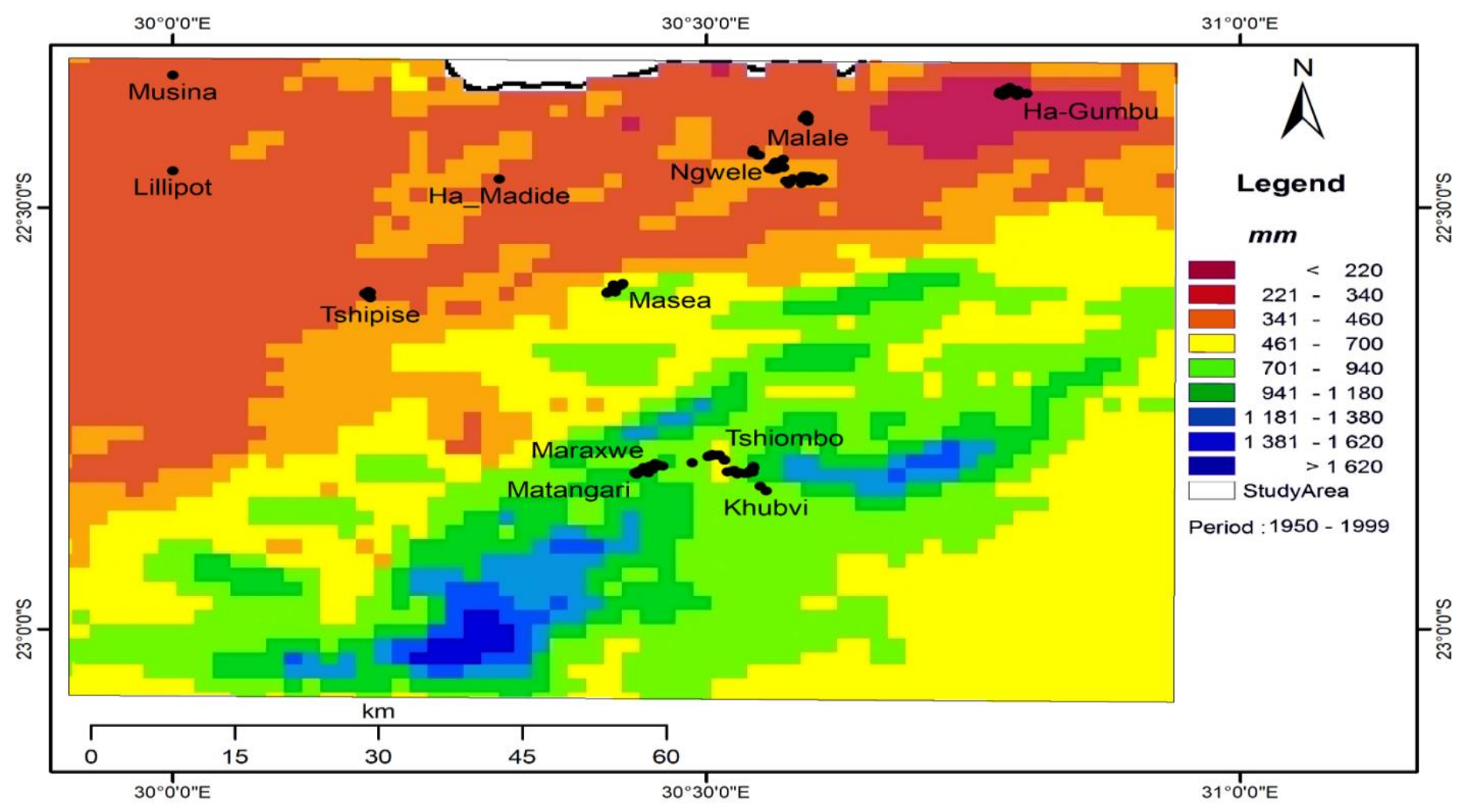

\section{FIGURE 2: Annual rainfall around selected villages of the location of irrigated smallholder agricultural enterprises in Vhembe District, Limpopo Province}

As alluded to by Omokanye et al (2018), rainfall provides water for drinking and plays a crucial role in dryland agricultural production. Precipitation influences the state of water resources in any given area (Omokanye et al, 2018). As suggested by Kala (2012), the amount of precipitation that an area receives dictates the nature of the agro-ecological setting that could prevail in that area. Also, the quantity of rainfall determines the level of streamflow and groundwater recharge in a catchment and therefore the availability of irrigation water. The Madimbo Corridor could be described as an arid low rainfall area with a maximum of 460mmpa. Only the village of Masea in the corridor received higher rainfall of 701 to $940 \mathrm{mmpa}$ (Figure 2). The Mutale Valley had rainfall of at least 461mmpa and above. The villages of Tshiombo, Maraxwe, and Matangari were well located for good annual rainfall of between 701 and $1380 \mathrm{mmpa}$.

\section{(b) Temperature}

The temperature of an area also has a great influence on the agricultural productivity of the area. 


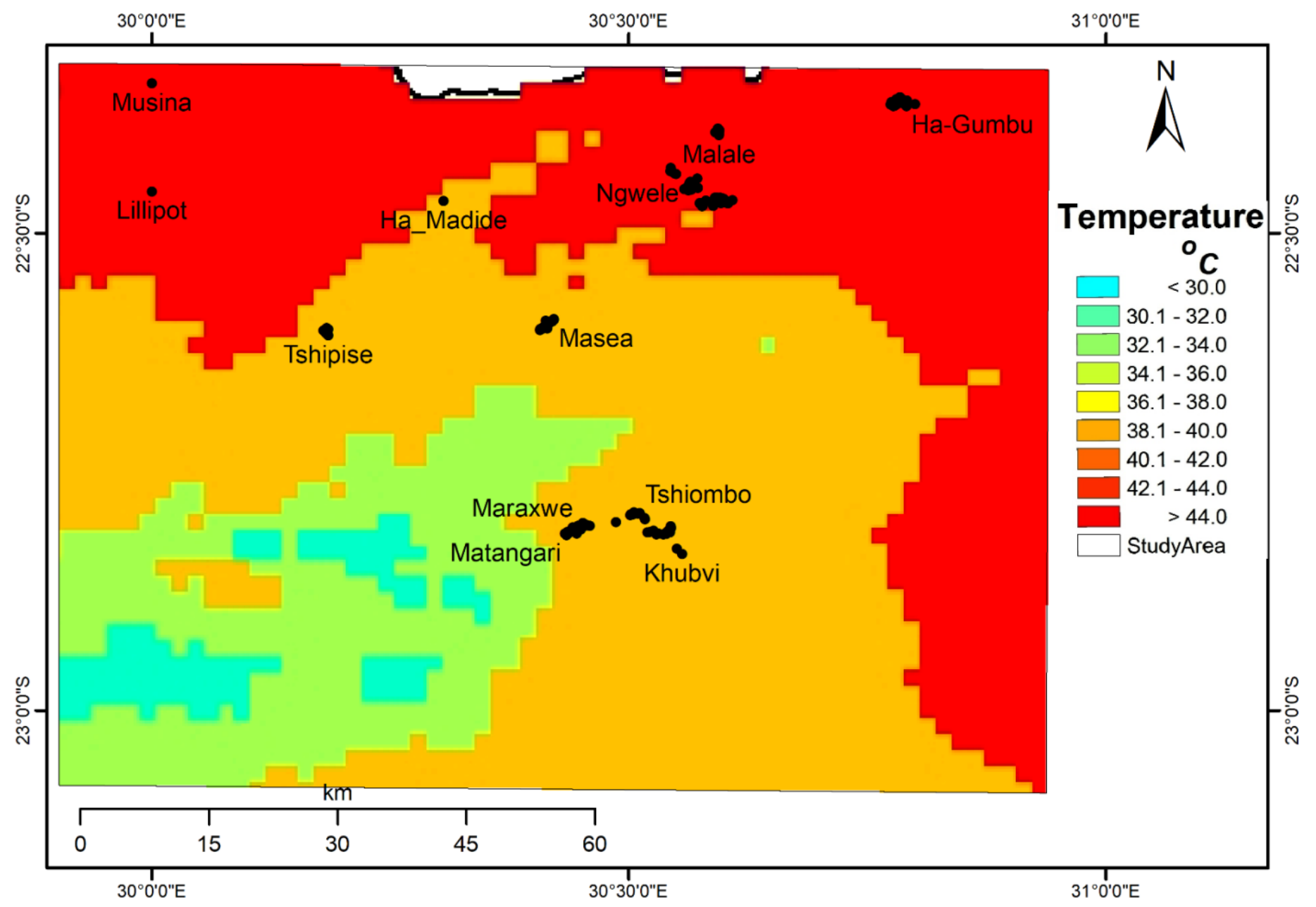

FIGURE 3: Annual temperature variation around selected villages of the location of irrigated smallholder agricultural enterprises in Vhembe District, Limpopo Province

The annual maximum temperatures in Madimbo Corridor ranged from $38.1{ }^{\circ} \mathrm{C}$ to as high as $44.0{ }^{\circ} \mathrm{C}$. On the contrary, annual maximum temperatures in Mutale Valley were relatively lower with some areas experiencing temperatures lower than $30.0^{\circ} \mathrm{C}$ while others recorded up to $40.0^{\circ} \mathrm{C}$. The study area is located in rather warmer areas associated with higher evapotranspiration rates and would therefore benefit from technologies promoting irrigation and crop water use efficiency.

\section{(c) Aridity}

To complete the geophysical characterization, an indication of aridity of the study area was essential, and this was measured by aridity index. Aridity index is a numerical indicator, which denotes the degree of dryness at a particular location based on the ratio of evapotranspiration to precipitation (Derya, et al., 2009). Maliva and Missimer (2012) defined aridity as a lack of moisture and the temporary reduction in the rainfall in an area, meanwhile, the increase in aridity represents a higher frequency of dry years over an area. The aridity indexes that are based on temperature and precipitation are commonly used all over the world (Baltas 2007; Deniz et al., 2011; Croitoru et al., 2013; Hrnjak et al., 2013; Moral et al., 2015). 


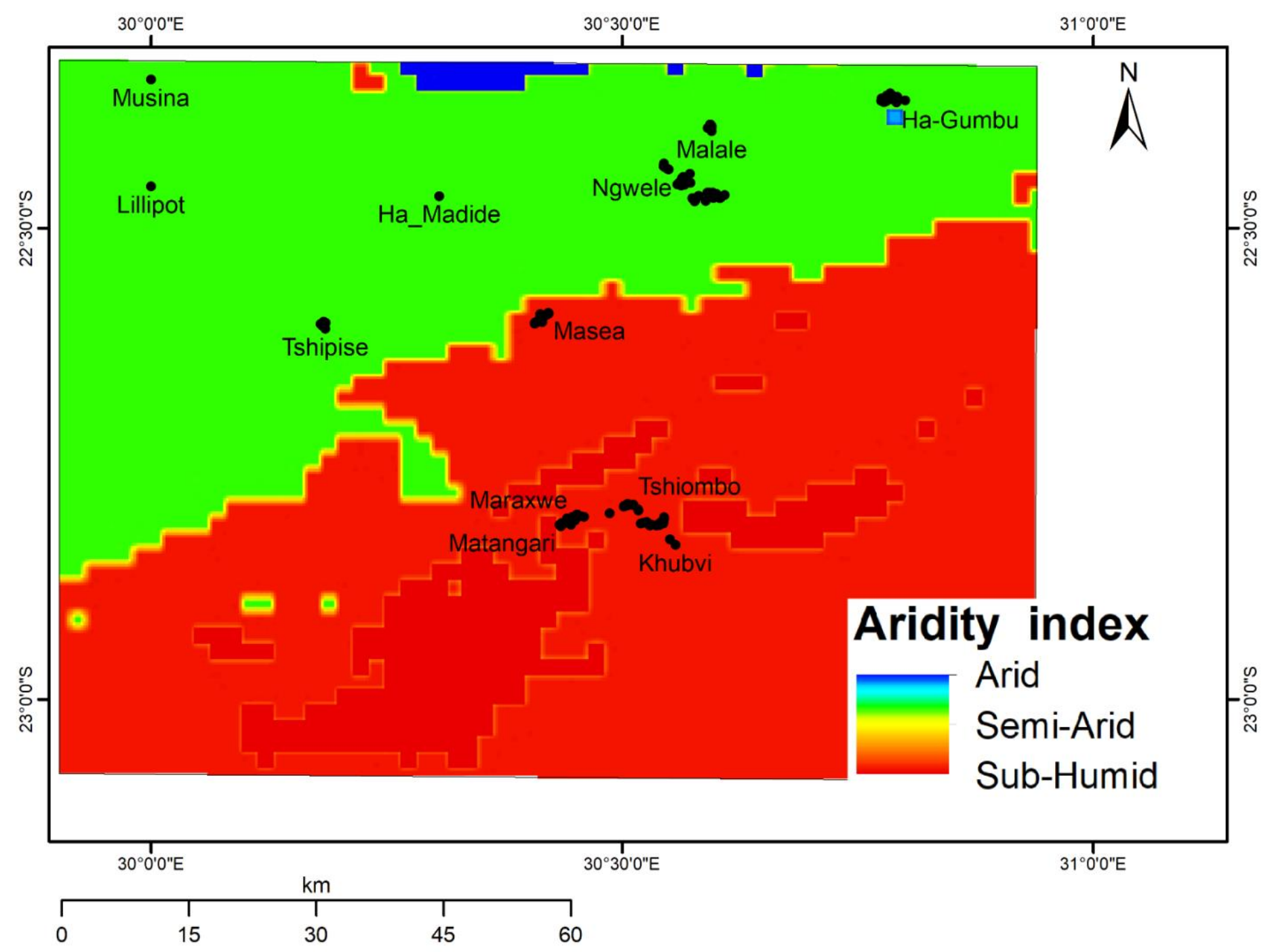

FIGURE 4: Map of aridity around selected villages of the location of irrigated smallholder agricultural enterprises in Vhembe District, Limpopo Province

As illustrated in Figure 4, the area in Madimbo Corridor varied from arid to semi-arid while that in Mutale Valley varied from semi-arid to sub-humid. An arid area is characterized by a severe lack of water resources to the extent of hindering the development of plants and vegetation. Such a lack is brought forth by the predominance of the evapotranspiration to the rate of precipitation (Derya, et al., 2009). Crop production in this area is difficult except under irrigation. Semi-arid areas are characterized by low mean annual rainfall which hinders farming (Aydin, 1995). Griffins (1985) defined the semi-arid regions as those where evapotranspiration exceeds potential precipitation. Consequently, the area experiences extended spells of the dry season and shorter wet periods. In the same logic, the sub-humid areas are relatively more ideal for crop production even under rainfed conditions. 
S. Afr. J. Agric. Ext.

Vol. 49 No. 3, 2021: 104-122.

http://dx.doi.org/10.17159/2413-3221/2021/v49n3a12848
Mavhungu, Nesamvuni, Tshikolomo, Raphulu, van Niekerk, Mpandeli \& Nesamvuni

(License: CC BY 4.0)

\subsection{Characterization of participants in women and youth smallholder agricultural enterprises}

The characterization of participants in women and youth ISAEs was based on (1) demography with a focus on (a) farmer position at the household, (b) farmer gender and age, (c) educational status of the head of household, household monthly income status, and (d) employment status farmer; (2) household livelihood with a focus on (a) household accommodation, (b) household source of energy, and (c) household appliances and cell phone owned; and (3) household food security with a specific focus on (a) daily food security and (b) seasonal food security.

\subsubsection{Demography}

The demographic features of participants in the ISAEs are explored in this section.

\section{(a) Participant position in the household.}

Most participants in ISAEs (59.52\%) were heads of their household, followed by those who were spouses $(19.39 \%)$ and children $(13.95 \%)$ in the households (Table 1).

TABLE 1: Position of participants of irrigated smallholder agricultural enterprises in households in Vhembe District, Limpopo Province

\begin{tabular}{|l|l|l|}
\hline Position in household & Number of respondents \\
\hline & Frequencies & \% \\
\hline Head of the household & 175 & 59.52 \\
\hline Spouse to the head of household & 57 & 19.39 \\
\hline Child to the head of household & 41 & 13.95 \\
\hline Others & 21 & 7.14 \\
\hline Total & $\mathbf{2 9 4}$ & $\mathbf{1 0 0}$ \\
\hline
\end{tabular}

According to Bembridge and Tshikolomo (1998), heads of households are the main decision-makers in rural farming households and as a result, the information they provide is more likely to reflect on farming and other developmental decisions of the household.

\section{(b) Gender and age}

The gender and age of participants in ISAEs are likely to influence their capacity to adapt to changes in the geoclimatic environment (IFPRI, 2015). In this study, women constituted 94.9 per cent of participants with men only constituting five per cent (Table 2). The study was, however, biased towards females in terms of sampling. Mulinyac (2017) reported that farmers within the ages of 30-34 years are likely to better understand issues involved in farming and are therefore regarded more armed with necessary information.

Only 24.15 per cent of the owners of ISAEs interviewed were youth between the ages of 18 to 35 years. In the same category of youth, nine per cent were found to be heads of households. 
TABLE 2: Gender and age of participants in irrigated smallholder agricultural enterprises in Vhembe District, Limpopo Province

\begin{tabular}{|c|c|c|}
\hline Demographic factor & Frequency & Per cent \\
\hline \multicolumn{3}{|l|}{ Gender of the farmer } \\
\hline \begin{tabular}{l|l} 
& Male
\end{tabular} & 15 & 5.10 \\
\hline Female & 279 & 94.9 \\
\hline \begin{tabular}{|l|l|} 
& Total \\
\end{tabular} & 294 & 100 \\
\hline \multicolumn{3}{|l|}{ Age of the farmer } \\
\hline \begin{tabular}{l|l}
$18-35$ years \\
\end{tabular} & 71 & 24.15 \\
\hline $36-59$ years & 155 & 52.72 \\
\hline$>60$ years & 68 & 23.13 \\
\hline Total & 294 & 100 \\
\hline \multicolumn{3}{|c|}{ Age of the head of household } \\
\hline \begin{tabular}{|l|l|} 
& $18-35$ years
\end{tabular} & 26 & 8.97 \\
\hline 36-59 years & 156 & 53.79 \\
\hline$>60$ years & 108 & 37.24 \\
\hline Total & 290 & 100 \\
\hline
\end{tabular}

The majority $(52.72 \%)$ of the ISAEs were adults between the ages of 36 to 59 years. Farmers older than 60 years were the second-highest category at 37.24 per cent. This observation supports Simotwo et al. (2018) who revealed that farmers were ageing. Older farmers could be resistant to change and thus may not see the need of employing new technologies and would prefer the traditional models of farming that they are familiar with other than adopting new methods (Fussel and Klein, 2006). Farm productivity has been shown to deteriorate with the farmer's age, especially among the smallholders who largely rely on their physical labour to execute many farming responsibilities (Uddin et al., 2014, Labbe et al., 2016).

\section{(c) Educational status and income of participants in irrigated smallholder agricultural enterprises}

The importance of education in successful developmental activities such as farming cannot be overemphasized. The level of education has a strong influence on the extent to which a farmer can access new information and technology, not only through improved literacy that enables the farmers to access written information but also through the increased ability to search for information using modern information technologies. Citing Appleton and Balihuta (1996), Oduro-Ofori et al. (2014) described the effect of education on agricultural productivity as cognitive and non-cognitive. Cognitive effects reportedly emphasize basic literacy and numeracy that farmers achieve from education while non-cognitive effects emphasize the change in the attitude of farmers who attended school due to improved discipline introduced by formal schooling.

About one in five (18.81\%) participants in ISAEs were completely illiterate, 27.84 per cent had primary education at most, with two in five (39.86\%) having had some secondary/high school education. Only $11.34 \%$ of respondents had a college or university education (Table 3). Reading and writing are basic conditions for farmers to have the ability to access information available in written and electronic media (O'Brien et al., 2004a). As depicted in Table 3, the majority (68.3\%) of ISAEs had an income of between R1001 to R5000. The immediate 
S. Afr. J. Agric. Ext.

Vol. 49 No. 3, 2021: 104-122.

http://dx.doi.org/10.17159/2413-3221/2021/v49n3a12848
Mavhungu, Nesamvuni, Tshikolomo, Raphulu, van Niekerk, Mpandeli \& Nesamvuni

(License: CC BY 4.0)

second was the category that earned an income of R5001 to R8000. As stated by Ijatuyi et al. (2017), income is a potent proxy for livelihood.

As highlighted, literature is explicit about the five pillars of livelihood which includes financial capital (stocks of money or assets in liquid form), natural capital (land, water, and biological resources), social capital (rights or claim derived from group membership), physical capital (infrastructure, resources created through economic production), and human capital (Ijatuyi et al., 2017).

TABLE 3: Education and income levels of participants in irrigated smallholder agricultural enterprises in Vhembe District, Limpopo Province

\begin{tabular}{|c|c|c|}
\hline Education and income categories & Frequency & Per cent \\
\hline \multicolumn{3}{|l|}{ Educational information } \\
\hline \begin{tabular}{l|l} 
& Never went to school
\end{tabular} & 46 & 15.81 \\
\hline ABET & 15 & 5.15 \\
\hline Primary Education & 81 & 27.84 \\
\hline Secondary school & 116 & 39.86 \\
\hline Tertiary Education & 33 & 11.34 \\
\hline Total & 291 & 100 \\
\hline \multicolumn{3}{|l|}{ Monthly income status (Rand) } \\
\hline $\mid \leq 1000$ & 25 & 8.50 \\
\hline $1001-5000$ & 200 & 68.03 \\
\hline $5001-8000$ & 44 & 14.97 \\
\hline $8001-15000$ & 12 & 4.08 \\
\hline $15001-30000$ & 12 & 4.08 \\
\hline$>30000$ & 1 & 0.34 \\
\hline Total & 294 & 100 \\
\hline \multicolumn{3}{|l|}{ Household received social grant } \\
\hline \begin{tabular}{|l|l} 
& Receive social grant \\
\end{tabular} & 221 & 77.00 \\
\hline Do not receive social grant & 66 & 23.00 \\
\hline \begin{tabular}{l|l} 
& Total \\
\end{tabular} & 287 & 100 \\
\hline \multicolumn{3}{|l|}{ Type of Grant received } \\
\hline \begin{tabular}{l|l} 
& Child grant \\
\end{tabular} & 147 & 63.36 \\
\hline Pension grant & 85 & 36.64 \\
\hline Total & 232 & 100 \\
\hline
\end{tabular}

Since more participants in ISAEs were women the majority $(77 \%)$ were receiving grants. Of the grant recipients, the majority $(63.36 \%)$ were child grant beneficiaries. The second type of grant $(36.64 \%)$ was a pension grant that is offered to those participants in ISAEs that are over 60 years. 
S. Afr. J. Agric. Ext.

Vol. 49 No. 3, 2021: 104-122.

http://dx.doi.org/10.17159/2413-3221/2021/v49n3a12848
Mavhungu, Nesamvuni, Tshikolomo, Raphulu, van Niekerk, Mpandeli \& Nesamvuni

(License: CC BY 4.0)

\section{(d) Employment status of participants in irrigated smallholder agricultural enterprises}

The employment status of participants in ISAEs tends to have some influence on their adaptive capacity to adverse effects of business risks. The participants in ISAEs may need to be employed elsewhere to supplement the farming income and be able to buy required inputs to mitigate the adverse effects of business risks. For these participants, involvement in additional employment increases their adaptive capacity and makes their agricultural enterprises recover faster from the occurrence of an adverse event. In this study, 54.61 per cent of participants in ISAEs were self-employed with an associated 34.04 per cent being full-time farmers (Table 4).

TABLE 4: Employment status of participants in irrigated smallholder agricultural enterprises in Vhembe District, Limpopo Province

\begin{tabular}{|l|l|l|}
\hline Employment status & Frequency & Percent \\
\hline Self-employment & 154 & 54.61 \\
\hline Full-time Farmer & 96 & 34.04 \\
\hline Public servants & 10 & 3.55 \\
\hline Unemployed & 8 & 2.84 \\
\hline Other & 14 & 4.96 \\
\hline Total & $\mathbf{2 8 2}$ & $\mathbf{1 0 0}$ \\
\hline
\end{tabular}

A lesser number of the participants were employed in the public service $(3.55 \%)$ with $2.84 \%$ describing themselves as unemployed.

\subsubsection{Household livelihoods}

\section{(a) Type of housing}

The type and quality of a house owned by a farmer tend to be positively influenced by the amount of income earned and may positively be associated with the capacity of the farmer to manage his / her agricultural enterprise. Farmers earning higher incomes are expected to afford better houses compared to their lower-income counterparts. Accordingly, ISAE participants with higher incomes are expected to reside in better quality houses than their lower-income counterparts.

The ISAE participants and other members of the community may, however, be beneficiaries of the government housing scheme and own higher-quality houses even if their income levels are low, hence the interest on the source of funding for house construction. The majority of ISAE participants had multiple roomed houses $(65.31 \%)$ and some $(31.98 \%)$ had multiple roomed houses with separate rondavels (Table 5).

The building materials used were cement bricks with roof corrugated iron $(54.42 \%)$ and walls of cement bricks with tile roofs $(23.81 \%)$. The majority $(67.24 \%$ ) had between five and eight rooms followed by 18.43 per cent with less than four rooms. The toilets were located outside in most households $(89.46 \%)$ and only seven per cent had inside flushing toilets and an outside pit toilet. 
S. Afr. J. Agric. Ext.

Vol. 49 No. 3, 2021: 104-122.

http://dx.doi.org/10.17159/2413-3221/2021/v49n3a12848
Mavhungu, Nesamvuni, Tshikolomo, Raphulu, van Niekerk, Mpandeli \& Nesamvuni

(License: CC BY 4.0)

TABLE 5: Housing accommodation of participants in irrigated smallholder agricultural enterprises in Vhembe District, Limpopo Province

\begin{tabular}{|c|c|c|}
\hline Type of housing accommodation & Frequency & Per cent \\
\hline \begin{tabular}{l|l} 
Single roomed house
\end{tabular} & 7 & 2.38 \\
\hline Cluster of rondavels & 1 & 0.34 \\
\hline Multiple roomed house & 192 & 65.31 \\
\hline Multiple roomed house with separate rondavels & 94 & 31.98 \\
\hline Total & 294 & 100 \\
\hline \multicolumn{3}{|l|}{ Type of building material used } \\
\hline \begin{tabular}{l|l} 
Walls of forest timber with thatch roof
\end{tabular} & 5 & 1.70 \\
\hline Walls of mud bricks with thatch roof & 5 & 1.70 \\
\hline Walls of mud bricks with a roof of corrugated iron & 29 & 9.86 \\
\hline Walls of cement bricks with thatch roof & 25 & 8.50 \\
\hline Walls of cement bricks with a roof of corrugated iron & 160 & 54.42 \\
\hline Walls of cement bricks with tile roof & 70 & 23.81 \\
\hline Total & 294 & 100 \\
\hline \begin{tabular}{|l|l|} 
Total \\
\end{tabular} & & \\
\hline \multicolumn{3}{|l|}{ Number of rooms } \\
\hline$\leq 4$ & 54 & 18.43 \\
\hline $5-8$ & 197 & 67.24 \\
\hline $9-12$ & 40 & 13.65 \\
\hline$>13$ & 2 & 0.68 \\
\hline \begin{tabular}{l|l|} 
& Total \\
\end{tabular} & 293 & 100 \\
\hline \multicolumn{3}{|l|}{ Location of toilets } \\
\hline \begin{tabular}{l|l} 
Outside pit toilet
\end{tabular} & 263 & 89.46 \\
\hline Inside flushing toilet & 6 & 2.04 \\
\hline Outside pit and inside flushing toilets & 22 & 7.48 \\
\hline No toilets & 3 & 1.02 \\
\hline Total & 294 & 100 \\
\hline
\end{tabular}

\section{(b) Energy supply}

Energy supply to households in the study area is shown in Table 6. Electricity allows access to information through TV media and telephone. Adaptive capacity is highly dependent on the capacity of farmers and their families to access key information and to collectively self-organize (Jones and Boyd, 2011). All participants in ISAEs had access to electricity. About 88.44 per cent used prepaid electricity which was a sign of good management to their household cash-flows. Only $11.56 \%$ had metered electricity. The majority $(89.58 \%)$ paid at most R500 per month with about 10 per cent paying over R500.00 per month (Table 6). 
S. Afr. J. Agric. Ext.

Vol. 49 No. 3, 2021: 104-122.

http://dx.doi.org/10.17159/2413-3221/2021/v49n3a12848
Mavhungu, Nesamvuni, Tshikolomo, Raphulu, van Niekerk, Mpandeli \& Nesamvuni

(License: CC BY 4.0)

TABLE 6: Energy supply to households of participants in irrigated smallholder agricultural enterprises in Vhembe District, Limpopo Province

\begin{tabular}{|l|l|l|l|}
\hline \multicolumn{2}{|l|}{ Energy supply } & Frequency & Per cent \\
\hline \multicolumn{2}{|l|}{ Access to electricity in the household } & & \\
\hline & Access to electricity & 294 & 100 \\
\hline & No access to electricity & 0 & 0 \\
\hline & Total & 294 & 100 \\
\hline Type of electricity & & \\
\hline & Metered & 34 & 11.56 \\
\hline & Prepaid & 260 & 88.44 \\
\hline & Total & 294 & 100 \\
\hline Cost of electricity (Rand /months) & & \\
\hline & $\leq 500$ & 258 & 89.58 \\
\hline & $501-1000$ & 18 & 6.25 \\
\hline & $1001-2000$ & 10 & 3.47 \\
\hline & $>2001$ & 2 & 0.69 \\
\hline & Total & $\mathbf{2 8 8}$ & $\mathbf{1 0 0}$ \\
\hline
\end{tabular}

\section{(c) Household equipment}

Table 7 shows the equipment that was owned by households of participants in ISAEs in the area under study. All participants interviewed owned a stove and refrigerator. Also, 96.76 per cent owned a radio, 78.61 per cent had an aerial TV set while 87.45 per cent owned a DSTV set. The participants in ISAEs would therefore be expected to have easy access to radio and TV transmitted information.

TABLE 7: Household equipment owned by participants in irrigated smallholder agricultural enterprises in Vhembe District, Limpopo Province

\begin{tabular}{|l|l|l|l|l|l|l|}
\hline & \multicolumn{2}{l}{ Yes } & No & Total & \\
\hline & Frequency & Percentage & Frequency & Percentage & Frequency & Percentage \\
\hline Stove & 258 & 100 & 0 & 0 & 258 & 100 \\
\hline Fridge & 294 & 100 & 0 & 0 & 294 & 100 \\
\hline Radio & 261 & 96.67 & 9 & 3.33 & 270 & 100 \\
\hline Aerial TV set & 147 & 78.61 & 40 & 21.39 & 187 & 100 \\
\hline Dstv set & 223 & 87.45 & 32 & 12.55 & 255 & 100 \\
\hline Donkey cart & 62 & 36.26 & 109 & 63.74 & 171 & 100 \\
\hline Bicycle & 27 & 13.57 & 172 & 86.43 & 199 & 100 \\
\hline Motorbike & 21 & 26.58 & 58 & 73.42 & 79 & 100 \\
\hline Sedan & 49 & 48.51 & 52 & 51.49 & 101 & 100 \\
\hline LDV & 99 & 65.56 & 52 & 34.44 & 151 & 100 \\
\hline
\end{tabular}


Perhaps important for transport provision in running their agricultural enterprises, 65.56 per cent of participants in ISAEs owned a light delivery vehicle, 48.51 per cent owned a sedan, 36.26 per cent had a donkey cart while 26.58 per cent owned a motorbike.

\section{(d) Communication equipment}

Table 8 depicts the extent to which participants in ISAEs owned the means of communication and a door to the digital world cell phone.

TABLE 8: Ownership of communication equipment (cell phones) by participants in irrigated smallholder agricultural enterprises in Vhembe District, Limpopo Province

\begin{tabular}{|l|l|l|l|}
\hline \multicolumn{2}{|l|}{ Cell phone equipment ownership } & Frequency & Per cent \\
\hline \multicolumn{2}{|l|}{ Number of males owning cell phones } & & \\
\hline & Zero & 18 & 6.19 \\
\hline One & 113 & 38.83 \\
\hline & Two & 97 & 33.33 \\
\hline & Three & 55 & 18.90 \\
\hline & $\geq$ Four & 8 & 2.75 \\
\hline & Total & 291 & 100 \\
\hline Number of females owning cell phones & & \\
\hline & Zero & 2 & 0.69 \\
\hline & One & 83 & 28.63 \\
\hline & Two & 127 & 43.79 \\
\hline & Three & 43 & 14.83 \\
\hline & $\geq$ Four & 35 & 12.07 \\
\hline & Total & $\mathbf{2 9 0}$ & $\mathbf{1 0 0}$ \\
\hline
\end{tabular}

Some 38.83 per cent of male participants in ISAEs owned one cell phone compared with 28.63 per cent of female participants. Some 33.3 per cent of males owned two cell phones compared to 43.79 per cent of their female counterparts. The likelihood of having more than one cell phone was due to lack of network which varied with the type of service providers. At the most, it was still significant to note that 18.90 per cent of the male participants in ISAEs had three phones compared to 14.83 per cent of the females. As reported, 12.07 per cent of female participants owned more than four cell phones. The means of communication seems to be more with female than male smallholder entrepreneurs.

\subsubsection{Household food security}

Access to food is an important aspect of characterizing participants in ISAEs and may be assessed through the use of various indicators. The choice of an indicator is informed by factors such as the feasibility of the measure and the capability to provide a multidimensional scale (Frangillo, 2000). Some indicators are categorized as process indicators reflecting both food supply and food access whereas others are regarded as outcome indicators used as proxies for food consumption (Frankenberger, 1992). The study investigated seasonal and daily food supplies for households of participants in ISAEs. 


\section{(a) Seasonal food supply}

Respondents were asked pertinent questions to assess the level of household food supply across seasons as guided by Bickel et.al. (2000). Based on Frangillo et al.(1999), households with low levels of supply of nutritious food were regarded as food insecure.

TABLE 9: Seasonal supply of food to households of participants in irrigated smallholder agricultural enterprises in Vhembe District, Limpopo Province

\begin{tabular}{|l|l|l|l|l|l|l|}
\hline & \multicolumn{2}{|l|}{ Yes } & No & \multicolumn{2}{l|}{ Total } \\
\hline & Frequency & Percentage & Frequency & Percentage & Frequency & Percentage \\
\hline Adequate food supply & 270 & 91.84 & 24 & 8.16 & 294 & 100 \\
\hline Seasons with fewer meals & 60 & 20.91 & 227 & 79.09 & 287 & 100 \\
\hline Skip meals & 36 & 14.46 & 213 & 85.54 & 249 & 100 \\
\hline Go to bed without meals & 7 & 2.92 & 233 & 97.08 & 240 & 100 \\
\hline
\end{tabular}

In this study, up to 91.84 per cent of the ISAE participants indicated that they had adequate food supply. The majority of participants $(79.09 \%)$ also pointed out that they had no seasonal shortage of food (Table 9). Accordingly, the participants revealed that they never experienced situations where they had to skip a meal (85.54\% of respondents) or go to bed without a meal $(97.08 \%)$. Perhaps rather unexpected were the responses of 81.15 per cent of participants who felt summer was the most difficult season for food supply while 11.48 per cent thought the winter season was rather difficult. With summer being the production season of most crops even under rainfed conditions, one would not expect it to be the most difficult season for food supply in the area under study.

\section{(b) Daily food supply}

With regards to the daily supply of food to ISAE households, respondents were asked to provide general perceptions on the number of meals per day and numbers during difficult periods.

TABLE 10: Daily supply of food to households of participants in irrigated smallholder agricultural enterprises in Vhembe District, Limpopo Province

\begin{tabular}{|l|l|l|l|}
\hline \multicolumn{2}{|l|}{} & Frequency & Per cent \\
\hline Number of meals per day & & \\
\hline & One & 1 & 0.34 \\
\hline & Two & 54 & 18.56 \\
\hline Three & 231 & 79.38 \\
\hline & Four & 3 & 1.03 \\
\hline & Five & 2 & 0.69 \\
\hline & Total & 291 & 100 \\
\hline Meals per day hardest period & & \\
\hline & None & 1 & 0.44 \\
\hline
\end{tabular}




\begin{tabular}{|l|l|l|l|}
\hline & One & 18 & 7.96 \\
\hline & Two & 112 & 49.56 \\
\hline & Three & 91 & 40.27 \\
\hline & Four & 4 & 1.77 \\
\hline & Total & $\mathbf{2 2 6}$ & $\mathbf{1 0 0}$ \\
\hline Meals per day other period & & \\
\hline & None & 1 & 0.44 \\
\hline & One & 7 & 3.08 \\
\hline & Two & 44 & 19.38 \\
\hline & Three & 172 & 75.77 \\
\hline & Four & 3 & 1.32 \\
\hline & Total & $\mathbf{2 2 7}$ & $\mathbf{1 0 0}$ \\
\hline
\end{tabular}

About four in five $(79.38 \%)$ of participants indicated that they generally had three meals per day with two in five $(40.27 \%)$ having received the same number of meals during difficult times while three in four $(75.77 \%)$ participants had the same number of meals outside the difficult times (Table 10). The provision of three meals per day in the majority $(79.38 \%$ ) of ISAE households tends to support their earlier view that food supply was generally adequate. It is worth noting, however, that half $(49.56 \%)$ of respondents received two meals per day during difficult periods with fewer $(19.38 \%)$ of them having received the same number of meals outside the difficult periods.

\section{(c) Reasons for fewer meals}

As alluded to, half (49.56\%) of participants in ISAEs received only two meals per day during difficult periods with one in five $(19.38 \%)$ of them having received the same number of meals outside the difficult periods. It was therefore deemed necessary to establish the main reasons for those ISAE households not being able to provide three meals that would cater for breakfast, lunch, and dinner.

TABLE 11: Reasons for fewer meals in some households of participants in irrigated smallholder agricultural enterprises in Vhembe District, Limpopo Province

\begin{tabular}{|l|l|l|l|}
\hline \multicolumn{2}{|l|}{ Reason } & Frequency & Percent \\
\hline & Lack of enough money to buy food & 55 & 25.20 \\
\hline & Shortage of Food & 3 & 1.10 \\
\hline & Summer days are longer and require more food than other seasons & 43 & 19.30 \\
\hline & Produce on the farm are not yet ready & 116 & 54.40 \\
\hline & Total & $\mathbf{2 1 7}$ & $\mathbf{1 0 0}$ \\
\hline
\end{tabular}

The majority (54.4\%) of ISAE households provided fewer meals because the produce on their farms was not yet ready for consumption (Table 11). One in four $(25.2 \%)$ of the respondents indicated that they lacked the money to buy food, hence the provision of fewer meals as a survival strategy. About one in five (19.3\%) of the respondents suggested that they provided fewer meals as summer days are longer and require more food, a reason that seemed to contradict the expectation. 
S. Afr. J. Agric. Ext.

Vol. 49 No. 3, 2021: 104-122.

http://dx.doi.org/10.17159/2413-3221/2021/v49n3a12848
Mavhungu, Nesamvuni, Tshikolomo, Raphulu, van Niekerk, Mpandeli \& Nesamvuni

(License: CC BY 4.0)

\section{CONCLUSIONS}

Considering the geophysical environment, the study area had variable precipitation with low rainfall (at most 460 mmpa) received by villages along the Madimbo Corridor and medium to high rainfall (701 to $1380 \mathrm{mmpa}$ ) received by those along the Mutale Valley. The annual maximum temperatures ranged from $38.1{ }^{\circ} \mathrm{C}$ to $44.0{ }^{\circ} \mathrm{C}$ (Madimbo Corridor) and $30.0^{\circ} \mathrm{C}$ to $40.0^{\circ} \mathrm{C}$ (Mutale Valley). The study area relied on surface water supplemented by groundwater which was utilized more at Madimbo Corridor compared to Mutale Valley. The area was characterized as semi-arid to sub-humid, hence technologies for efficient use of irrigation water should be promoted.

With regards to demography, participants in ISAEs were mostly female (94.9\%), and adults of 36-59 years $(52.72 \%)$ with rather little education where $27.84 \%$ possessed primary while $39.86 \%$ had secondary education. The majority of participants $(88.65 \%)$ were not formally employed (54.61\% were self-employed and $34.04 \%$ were full-time farmers). Participants in ISAE probably experienced some level of poverty with 68.03 per cent receiving low household incomes (R1 001 to R5 000 / month) and 77 per cent dependent on social grants.It was interesting to note that 65.31 per cent of participants stayed in houses with multiple rooms mostly with cement brick walls and corrugated iron roofs $(54.42 \%)$. They all had access to electricity and possessed a stove and fridge. Majority owned radio (96.67\%), digital satellite television $(87.45 \%)$, and vehicle (65.56\%). They all had cellphones except for 6.19 per cent of males.

Also worth noting is the fact that 91.84 per cent of ISAE participants reported having had an adequate food supply with 79.38 having provided three meals per day. However, the situation was different during hard times where most (49.56\%) provided two meals with only 40.27 per cent maintaining three meals. As revealed by participants, the reason for the provision of fewer meals was mostly delayed maturity of farm produce.

\section{ACKNOWLEDGEMENT}

The authors would like to appreciate the Water Research Commission (WRC) for the funding of the study.

\section{REFERENCES}

ADAMS, S. 2013. WRC - leading the charge on groundwater research. Water Wheel. Groundwater Special Edition. 2013.

AYDIN, M. 1995. Water: Key ingredient in Turkish farming. Forum for applied research and public policy. A Quarterly Journal of the University of Tennessee. 10: 68-70.

BALLARD T., COATES, J, SWINDALE \& DEITCHLER. 2011. Household hunger scale: Indicator definition and measurement guide. Washington, DC: FANTA-2 Bridge, FHI 360.BALTAS, E.,(2007) Spatial distribution of climatic indices in northern Greece. Meteorol Appl 14:69-78.

BEMBRIDGE, T.J. \& TSHIKOLOMO, K.A. 1998. Communication and decision-making among fruit growers in the Phaswana area of Northern Province. South African Journal of Agricultural Extension, 27: 19-29. 
BICKEL, G. et al. Measuring food security in the United States: Guide to measuring household food security. USDA, Office of Analysis, Nutrition and Evaluation, USA, 2000.

CROITORU, A.E, PITICAR. A., IMBROANE A.M., BURADA, D.C. 2013. Spatio-temporal distribution of aridity indices based on temperature and precipitation in the extra-Carpathian regions of Romania. Theor Appl Climatol 112:597-607.

DENIZ, A., TOROS, H., INCECIK, S. 2011. Spatial variations of climate indices in Turkey. Int. J. Climatology 31(3):394-403.

DERYA, Ö., MEHMET, A., SÜHA, B., SERMET, Ö. \& TOMOHISA, Y. 2009. The use of aridity index to assess implications of climatic change for land cover in Turkey. Turk J Agric For (33), 305-314. doi:doi:10.3906/tar-0810-21.

FRANGILLO, E.A. 1999. Validation of measures of food insecurity and hunger. Journal of Nutrition. $129: 506$ -509 .

FRANKENBERGER, T.R. 1992. Indicators and data collection methods for assessing house-holds food security. Households Concepts, Indicators, Measurements. A technical Review. New York. UNICEF: 73 - 134.

FÜSSEL, H-M. \& KLEIN, R.J.T. 2006. Climate Change Vulnerability Assessments: An Evolution of Conceptual Thinking. Climate Change 75: 301-329.

GRIFFINS, J. 1985. Handbook of Applied Meteorology. (D. D. Houghton, and J. W. Sons, Eds.).

HRNJAK, I., LUKIĆ, T., GAVRILOV, M.B., MARKOVIĆ, S.B., UNKAŠEVIĆ, M. \& TOŠIĆ. I. 2013. Aridity in Vojvodina, Serbia. Theor Appl Climatol 115(1-2):323-332.

JONES, L. \& BOYD, E. 2011. Exploring social barriers to adaptation: insights from Western Nepal. Glob Environ Chang 21:1262-1274.

KALA, N., KURUKULASURIYA, P. \& MENDELSOHN, R. 2012. The impact of climate change on agroecological zones: Evidence from Africa. Environment and Development Economics, 17(6), 663-687. Retrieved from http://www.jstor.org/stable/26265545.

KOTIR, J. 2011. "Climate change and variability in Sub-Saharan Africa: a review of current and future trends and impacts on agriculture and food security," Environment, Development, and Sustainability: A Multidisciplinary Approach to the Theory and Practice of Sustainable Development, Springer, vol. 13(3), pages 587-605, June.

LEEDY, P.D. \& ORMROD, J.E. 2005. Practical research: Planning and design (8th Ed.). Upper Saddle Livelihood Improvement at Gubalafto District, North Wollo, Ethiopia. Agriculture 6 (27). Lynne Rienner Publishers.

Maliva, R.G. \& Missimer, T.M. 2012. Arid lands water evaluation and management. Environ Sci Eng 3(1948):806.

MORAL, F.J., REBOllO, F.J., PANIAGUA, L.L., GARCÍA-MARTÍN, A. \& HONORIO, F. 2015. Spatial distribution and comparison of aridity indices in Extremadura, southwestern Spain. Theor Appl Climatol. https :// doi.org/10.1007/s0070 4-015-1615-7.

MPANDELI, S. \& MAPONYA, P. 2014. Constraints and Challenges Facing the Small Scale Farmers in Limpopo Province, South Africa. Journal of Agricultural Science; Vol. 6, No. 4. 
S. Afr. J. Agric. Ext.

Vol. 49 No. 3, 2021: 104-122.

http://dx.doi.org/10.17159/2413-3221/2021/v49n3a12848
Mavhungu, Nesamvuni, Tshikolomo, Raphulu, van Niekerk, Mpandeli \& Nesamvuni

(License: CC BY 4.0)

MULINYA, C. 2017. Factors Affecting Small Scale Farmers Coping Strategies To Climate Change In Kakamega County In Kenya. Journal of Humanities and Social Science 22.

O’BRIEN, K., LEICHENKOB, R., KELKARC, U., VENEMAD, H., AANDAHLA, G., TOMPKINSA, H., JAVEDC, A., BHADWALC, S., BARGD, S., NYGAARDA, L. \& WESTA, J. 2004a. Mapping vulnerability to multiple stressors: climate change and globalization in India. Global Environmental Change 14 (2004) 303-313.

ODURO-OFORI, E., ABOAGYE, A.P. \& ACQUAYE, N.A.E. 2014. Effects of education on the agricultural productivity of farmers in the Offinso Municipality. International Journal of Development Research, 4(9): 1951-1960.

OMOKANYE, A., YODER, C., SREEKUMAR, L., VIHVELIN, L. \& BENOIT, M. 2018. On-farm Assessments of Pasture Rejuvenation Methods on Soil Quality Indicators in Northern Alberta (Canada). Sustainable Agriculture Research. 7. 74. 10.5539/sar.v7n2p74.

RANDELA, R., GROENEWALD, J.A. \& ALEMU, Z.G. 2006. Characteristics of potential successful and River, NJ: Prentice Hall. Science. 6 (2).

SIMOTWO, H.K., MIKALITSA S.M. \& WAMBUA B.N. 2018. Climate change adaptive capacity and smallholder farming in Trans-Mara East sub-Country, Kenya. Geoenvironmental Disasters, 5:5.

STATS SA (STATISTICS SOUTH AFRICA). 2016. Community Survey 2016: Basic Results for Limpopo. Statistics South Africa, Pretoria, South Africa.

TSHIKOLOMO, K.A., NESAMVUNI, A.E., STROEBEL, A. \& WALKER, S. 2012a. Water Supply and Requirements of Households in the Luvuvhu-Letaba Water Management Area of South Africa. International Journal of Business and Social Science, 3(3): 37-49.

UDDIN, M., BOKELMANN, W., \& ENTSMINGER J. 2014. Factors affecting farmers' adaptation strategies to environmental degradation and climate change effects: A farm level study in Bangladesh. Climate Retrieved from http://www.mdpi.com/2225-1154/2/4/223/htm. Vhembe IDP., 2017-2018.

WRC. 2009. Small-scale irrigation farming- Best management practices on selected irrigation schemes. Technical report. Republic of South Africa. 